\title{
Hybrid TV Scripts and Streamings: A Project Strategy for the Design of Connected and Convergent Interfaces to T-Commerce Applications
}

\author{
Marcelo Falco and Rachel Zuanon \\ Sense Design Lab, Ph.D. and Master's Design Program, Anhembi Morumbi University, Brazil
}

\begin{abstract}
Interactive digital television is at early stage as regards the interface design, especially in business transactions (t-commerce). Current attempts to transpose the problem related to linearity of narrative and temporal flows and audiovisual content obstruction by the interactive layer, although pointing out design perspectives - in addition to the structural and visual web patterns - are still insufficient as regards the design of interfaces connected and converged for t-commerce applications. This article considers that these problems arise from the structural basis that support television scripts and streamings. In this sense, this article proposes the hybridization between the linear model, inherited from analogue condition, and nonlinear model, intrinsic to digital media, as a methodological strategy aiming to strength the creation of interactive audiovisual content connected and convergent for this context.
\end{abstract}

Key words: Interface design, iDTV, t-commerce, second screen, connectivity, convergence.

\section{Introduction}

iDTV (interactive digital television) and Internet represent the possibility of access to a digital world of information and services. Consisting of a computerized system and operated via remote control, "television is one of the means of dissemination of information and mass entertainment, especially in Brazil where it is present in $90 \%$ of households" [1]. However, iDTV is at early stage as regards the interface design, especially in business transactions (t-commerce) [2, 3]. The challenges of research and development in iDTV are broad and not fully investigated $[4,5]$. Interactivity possibilities for iDTV not only represent dialogic perspectives between the television viewer and television-taking them to the

Corresponding author: Marcelo Falco, professor, research fields: iDTV, T-commerce, second screen, connectivity, convergence.

Rachel Zuanon, Ph.D., professor, research fields: iDTV, T-commerce, second screen, connectivity, convergence. active condition of teleinteractor ${ }^{1}$ - but also announce paradigm shifts on the television audiovisual language - regarding its pre-production, production and post-production stages [6].

Unlike traditional narratives for analog television that have limitations $[7,8]$ as the viewing flexibility and access to audiovisual content-imposed by a context governed by linearity-interactive digital television enables the expansion of this content and their narratives between different languages and platforms, in narrative and nonlinear temporal flows and, thereby, configure convergent and transmedia contexts. This context restates the relevance of rethinking how interfaces are dialoguing with the

\footnotetext{
1 Television viewer refers to the individual that only "watches" television, that is, receives information, but does not establish a dialogic relationship with the contents. On the other hand, the interactor condition is related to interactive digital media, which enable the exchange of information between the individual, and the medium, as well as the possibility of this individual to transform content available according to their preferences. In this sense, the "teleinteractor" combines the features of television viewer and interactor and can be defined as one that, in addition to watching television, also interacts with the contents.
} 
teleinteractors, once this communication sets up "a change in how we view our relationship with the media" [9] in a convergence relation.

In the scope of interface design of many applications for iDTV, and more specifically for $\mathrm{t}$-commerce (business transactions in iDTV and object of this research), design perspectives, in addition to the structural and visual web patterns assimilated by e-commerce applications (electronic trading on the Internet) [10], are beginning to be outlined. The attempt of transposing the problem related to the linearity of the narrative and temporal flows can be identified in the contributions made by interactive videos for iDTV, in which the video and the use of elements of audiovisual language articulated to the interaction elements stand out, for example the case of Heineken Brewery [11] (Fig. 1). In the above-mentioned case, the teleinteractor views three options for the end of the video [A], for a period of time predetermined by the TV station [B]. The option chosen will be displayed at the iDTV interface [C]. In case the choice is not made by teleinteractor, one of the options is played randomly.

Another example is the interactive advertising of Kraft Foods [12], in which the teleinteractor can modify three times the video, through the selection of elements displayed in the show interface in the course of the narrative. These references, though opening perspectives for a nonlinear interaction with audiovisual content, do not impact the linear structure, on which the TV station's show schedule is drawn up, as they do not change the current duration set up for commercial advertising during the breaks of television

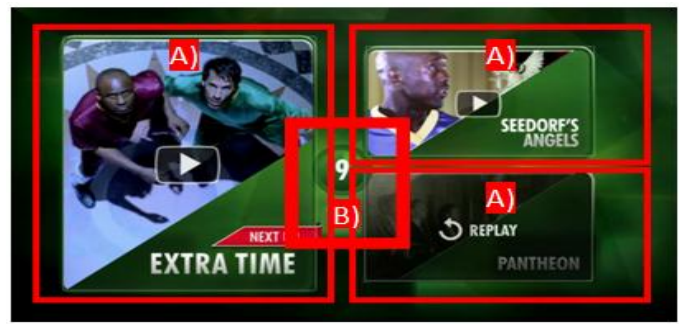

(a) broadcasts. In this regard, the choice of teleinteractor can be performed only at this period of time, otherwise it is automatically directed to one of the ends. These applications, from Heineken and Kraft Foods, consider the analog television business models, in this case understood by the commercial break and direct merchandising $[1,13]$, and are still employed by digital television.

In addition to this context, the problem of audiovisual content obstruction by the interactive layer also appears as one of the challenges in the interface design for t-commerce applications, and has found design paths dedicated to preserving the language of audiovisual media in the Second Screen or TV connected applications [14] by connecting interactive digital television interface to the mobile device interfaces, such as tablets and smartphones.

Such connectivity is currently being used as a way to separate the layers of audiovisual content and interactivity by focusing the main video exhibition in the iDTV interface and transfering the interactive information content for mobile devices interfaces. For instance, in the iDTV applications of NantMobile [15] (Fig. 2) and KlugTV [16, 17], in which the teleinteractor places their iPhone or iPad in front of the TV, so that the embedded application recognizes the commercial interface and displays complementary content to television narrative on the first screen of the mobile device interface [18]. This condition causes the teleinteractor to purchase products, access further information, among other interactions, in concurrent action to the exhibition of the audiovisual content related to the show broadcasted on iDTV.

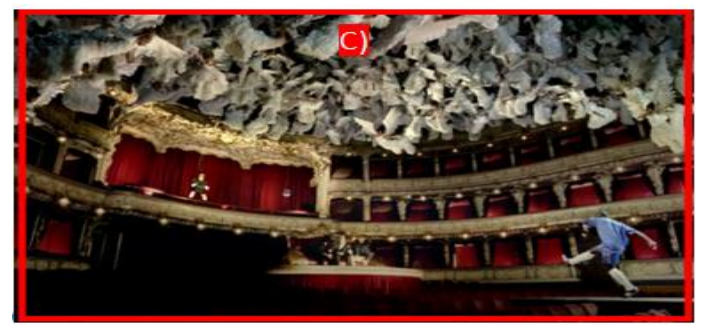

(b)

Fig. 1 Heineken advertising interactive video for iDTV [11]. A) Options of favorite end; B) Time for the teleinteractor to choose; C) Scene of the selected video. 


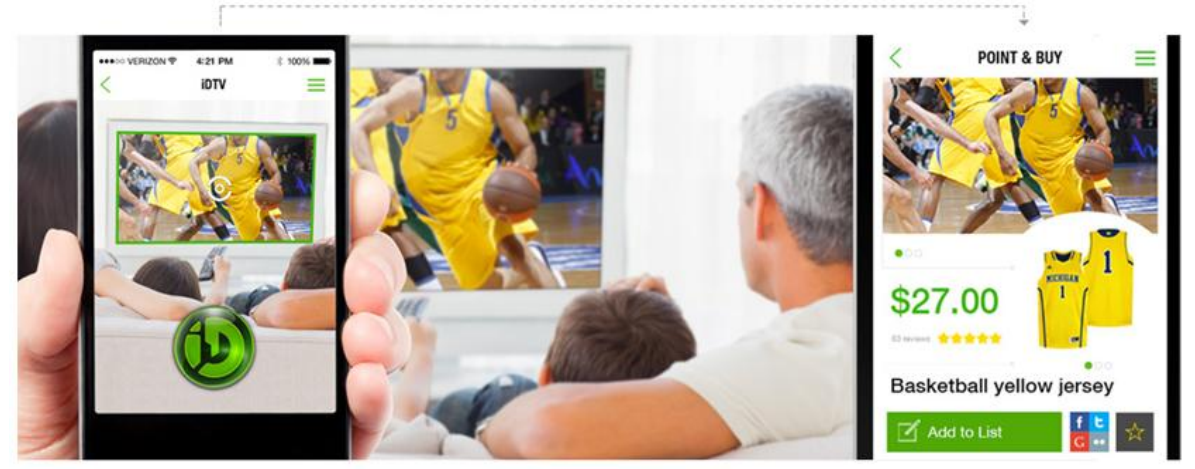

Fig. 2 iDTV interface of NantMobile that displays an additional content on iPhone or iPad [15].

These examples use as reference business transactions for mobile devices, they are called $\mathrm{m}$-commerce. Despite the interaction with tablet or smartphone interface as a design solution aimed to curb the obstruction and/or interruption of television content generated by visual overlay of interactivity layer, the connectivity does not leverage the convergence among the media by limiting the interaction with the content available only on mobile devices, without providing the construction of dialogical links with the content displayed on the TV interface [19, 20].

In this sense, the hypothesis presented in this article assumes that the design problems within the interfaces of iDTV applications, especially the t-commerce applications, arise in the structural basis that supports the design of television scripts and streamings. Thus, it is proposed that the linear models, inherited from the analog condition, and nonlinear models, intrinsic to digital media, are hybridized in order to enhance the creation of interactive audiovisual content connected and convergent for t-commerce applications, once the individual application of these models is insufficient for this purpose. It is noteworthy that the main results of this research come from the application of this methodological approach as an object of study developed by students of Digital Design Bachelor's Degree and Undergraduate Research of Anhembi Morumbi University, involved in the design of prototype applications for iDTV connected and convergent with second screen.

\section{Linear TV Scripts and Streamings}

Television works with the matrix of audiovisual language common on movies and videos, but it has developed genres and formats that are specific to it [2], such as news shows, documentaries, soap operas, series, sports shows, music shows, talk shows, interviews, among others [9]. Its schedule is conceived through television scripts and streamings, which are linear for analog television, both as regards its narrative and temporal structure.

The script is how content sequence and their respective durations are controlled. The linear script models are primarily structured in two columns, one dedicated to describing the scenes, the other aimed at sound specifications. The descriptive content covered in the script is fundamental and very important for the production and editing of audiovisual content, because there are elements and details of its production and post-production [21].

The television streaming uses the script as premise and, in this context, it follows the same linearity, foreseeing opening sequences, the amount and the stipulated time ${ }^{2}$ of TV show itself and commercial breaks in a show, as shown below in the television streaming developed by the authors for a 30-minute show prototype (Fig. 3).

In this sense, the TV station offers a range of audiovisual products that are interesting to the viewer

\footnotetext{
${ }^{2}$ Each show part should not last less than ten minutes, as well as the commercial break that should last more than two minutes and thirty seconds [22].
} 


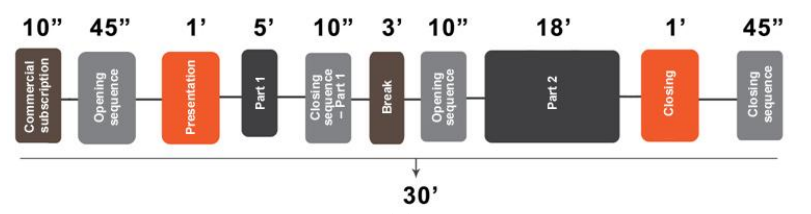

(a)

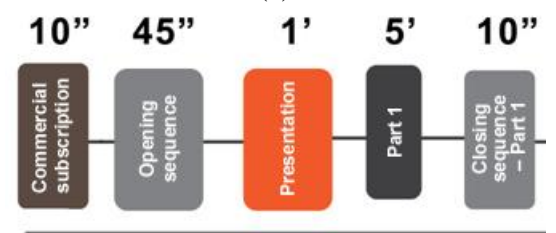

(b)

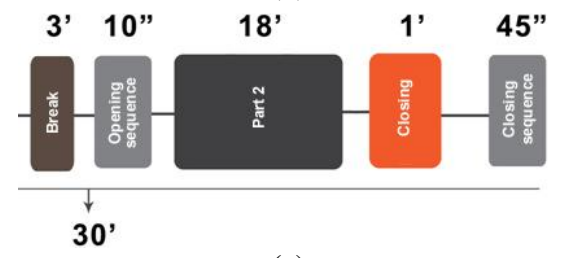

(c)

Fig. 3 Television streaming for a 30-minute show.

in exchange for part of their time dedicated to viewing products, services or brands displayed on the TV [23]. In addition to the commercial breaks, TV stations start to mention or show products in a seemingly casual way, through the so-called merchandising [24], thus, it is possible to shop these products presented in sales channels through the phone or the internet [25].

First used in the movies, nowadays merchandising is in every TV show [14]. It is often related to a promotional campaign and with the goal of highlighting the product in relation to others and to the environment in which it is inserted [26]. There are direct and indirect merchandising. In the direct merchandising, the product is displayed in the background and is related to show content, which can also be interpreted as a subliminal message ${ }^{3}$, since most of the time, there is no intention to sell that particular product, but it is intended to stablish their image in the viewer's subconscious. On the other hand, the indirect merchandising is used when the

\footnotetext{
3 Subliminal messages, as they are not perceived by the human conscious, but cannot be ignored [28]. There is criticism of its use once "the ultimate goal of the subliminal message is to manipulate people's minds. The inclusions, words, icons and ideas cannot be perceived by the consumer at a normal level of consciousness, so there is no option to accept or reject the message, as the advertising without stimuli."
}

advertisement is displayed during a television show, but not directly related to its content. In this case, the show host advertises or invites a third party to show it [1]. Sales or teleshopping channels are shows intended to the marketing and sale of products [27] and resemble the indirect merchandising because there is a host to demonstrate the product to the viewer.

These models of business transactions, which were developed in the context of a linear structure of analogue television, establish a one-way communication with the viewer, as regards the technological potential of the TV. However, with the arrival of iDTV, this technological potential is extended to the condition of interactive digital media, able to provide to commercial transactions new features aimed at establishing a two-way dialogue between television content and the teleinteractor.

\section{Nonlinear TV Scripts and Streamings}

Digital environments transform themselves. Textual, pictorial and sound elements become plastic and able to suffer changes and metamorphoses [3]. As regards the development of a digital project, five plans should be considered (Fig. 4): Strategy, Scope, Structure, Scheme and Surface. They constitute the conceptual frame to address the user experience and their tools involved in this construction.

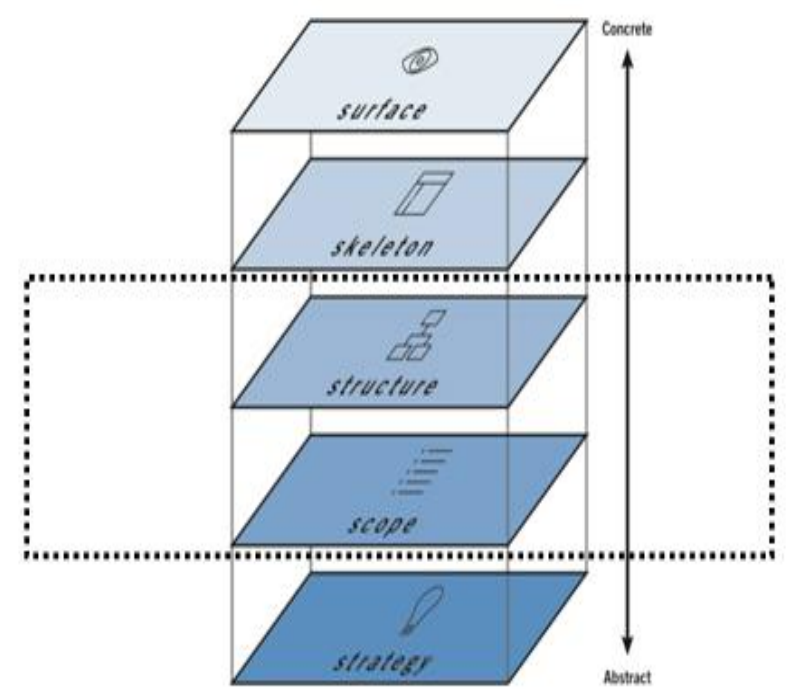

Fig. 4 Structure plans for interface design [29]. 


\section{Hybrid TV Scripts and Streamings: A Project Strategy for the Design of Connected}

and Convergent Interfaces to T-Commerce Applications

Nonlinear TV scripts and streamings are directly related to Scope and Structure plans. Scope refers to the definition of content and its functional specifications, explained earlier in the strategic plan. Structure plan is responsible for defining how the content is organized and structured for browsing and interaction in the digital world [29].

The process of transposing linearity, intrinsic to analogue television, to nonlinearity of the narrative flows, enabled by interactive digital media, considers the idea of rhizome by allowing open and complex paths and segments, full of deviations, and composed of segment and escape lines [30]. Rhizomes are visual schemes that associate specific symbols, graphs ${ }^{4}$, to the digital project.

The complexity of a diagram, such as a map or a metaphorical medium, which aims to show the path from one point to another, from one level of understanding to another [31], is directly linked to its interactive capability. The more options to choose, more elaborate becomes the corresponding map [6]. Similarly to the map ${ }^{5}$ developed by the authors for a prototype of iDTV application (Fig. 4).

This direct association between the Scope and Structure plans respectively to the television script and streaming, by breaking the paradigms of linearity, provides other perspectives to the design development of business transactions on television, in which the autonomy of the parties regarding the whole, sets a perception of interconnectivity able to transpose the traditional hierarchy model and information centralization [32].

In this regard, commercial transactions on TV are seemed as the condition of t-commerce applications and abandon the zero interactivity level, consisting of linear narratives from the beginning to the end; transact through the linear interactivity using the

\footnotetext{
${ }^{4}$ The graphs are made up of figures and graphic objects, such as circles, squares or any image that can be connected by relationships (connections), represented by lines and curves [33].

5 The maps provide a visual representation of the streaming among the different interfaces presented to the user [34].
}

remote control to zap channels and select menu items; and assume the Linguistics, Creation and Continuous Command interactivities, which provide the teleinteractor with filling out forms, writing messages and the manipulation of sound and/or visual elements [35].

However, despite all the potential design of digital interactive media and, therefore, subject to allocation to T-commerce applications, in this context, it continues the replication of transactional web models (e-commerce) that contribute to the distortion of television audiovisual language. This problem motivates the hypothesis proposed in this article that consists of the hybridization between the linear model, inherited from analogue condition, and nonlinear model, intrinsic to digital media, as a methodological strategy able to enhance the creation of interactive transactional audiovisual content, that are connected and convergent.

\section{Hybrid TV Scripts and Streamings}

The convergence of services and applications is a process that involves and uses several platforms and devices to receive contents, services, games, television shows, integration with mobile devices, among others [23]. The convergence among television and other digital devices, however, establishes a dialogue, which is not restricted to technology relationship [36], but it is extended to the content of their narratives, through the connectivity between their scripts, leading to the setting of interactive media streamings in order to broaden the teleinteractor experience.

Current proposals of integration between the audiovisual narratives and interactive content add to the model used in the construction of linear scripts, third and fourth columns aiming to describe the interaction and to present the interface storyboards, respectively [1]. However, such proposals are limited as to show graphical representation that preserves the linearity of narrative and temporal flows used in the scripts from the analog television as well as on the 


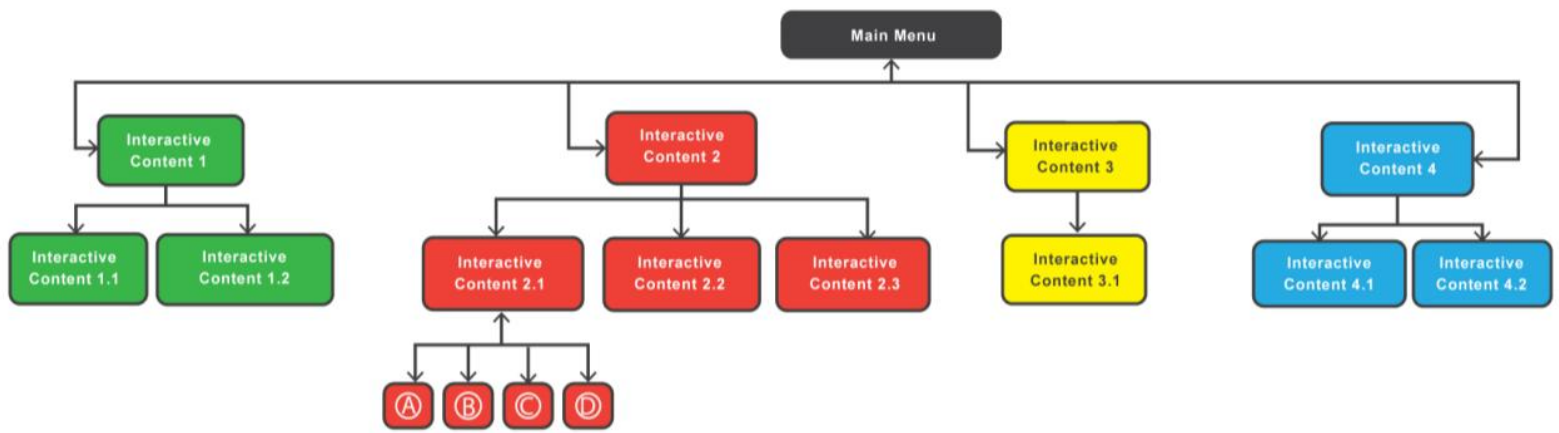

(a)

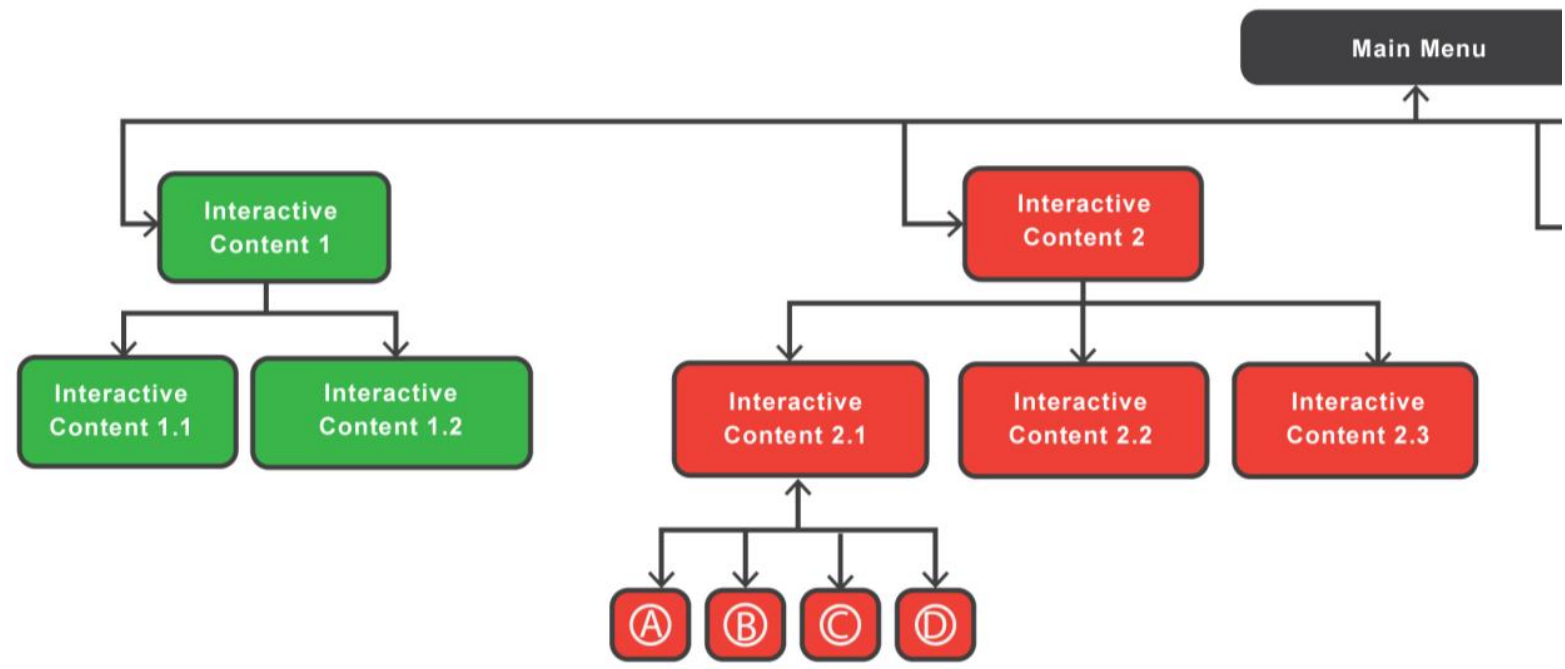

(b)

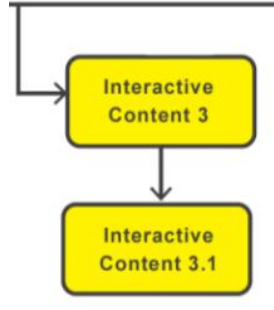

Fig. 5 Map for a T-commerce application for iDTV.

range of connective possibilities that rhizomatic network, represented by diagrams, can provide to the design development of interactive television applications.

The proposal of transposing the limitations of the script models and linear television streaming, inherited from analogue condition, and proposing a methodological strategy for the nonlinear television scripts and streamings within the iDTV uses as reference the diagram and taxonomy to organize levels or layers, from general to specific. Each level of

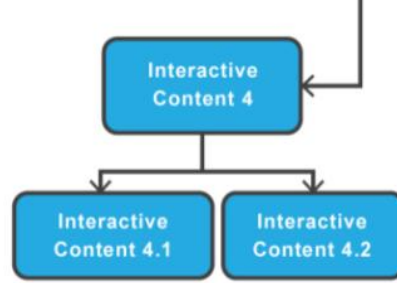

(c)

encapsulation indicates a level of abstraction and it is responsible for answering what it is and how the application and interactions work, representing connections as an area of a complex system [33]. For example, there is the hybridization, proposed by the authors, between the linear television streaming and the nonlinear diagram for the development of a T-commerce application (Fig. 5). In this context, hybridity constitutes a moment of revelation, a moment of freedom from which a new way is born [37]. 

and Convergent Interfaces to T-Commerce Applications

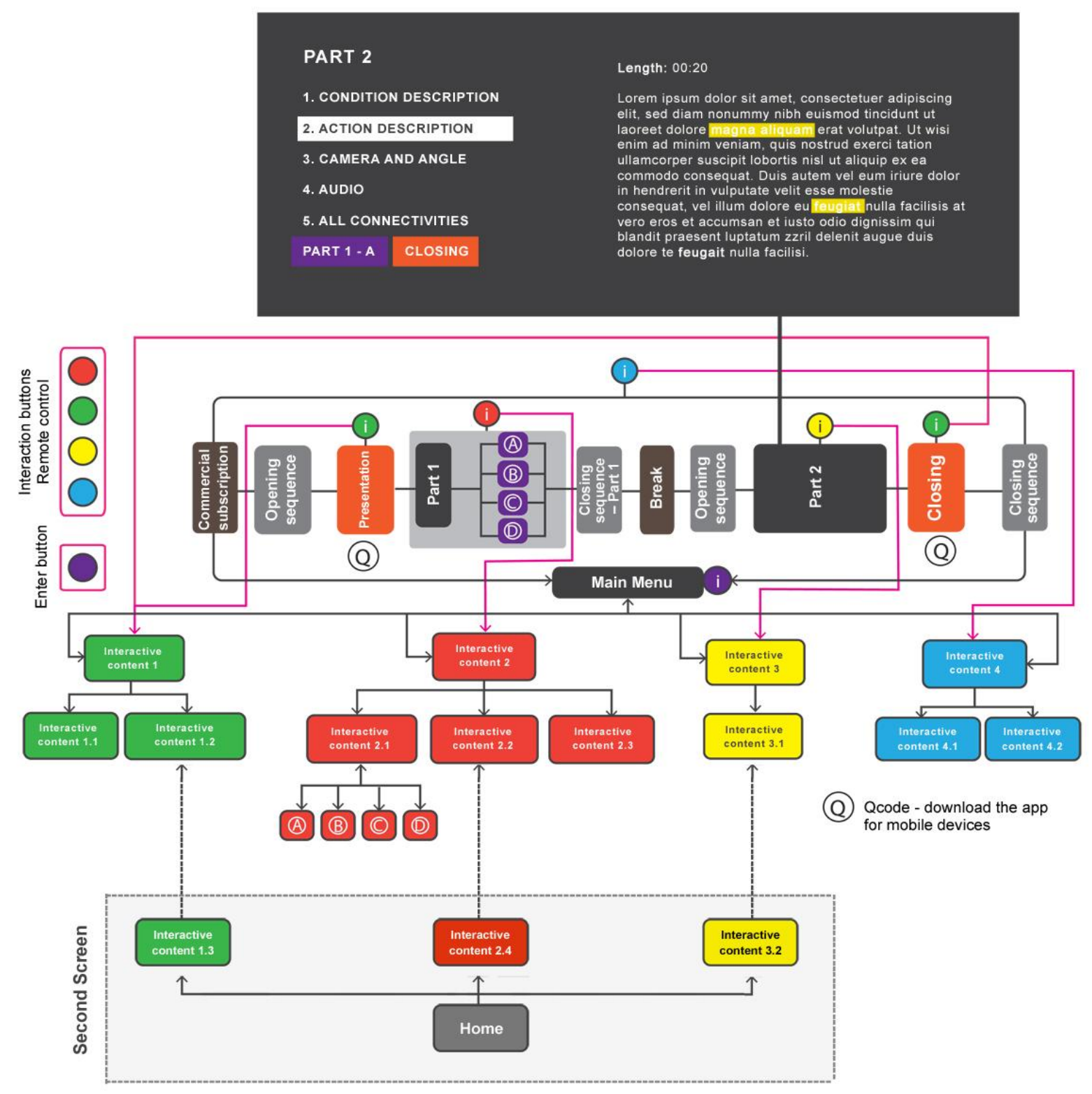

(a)

\section{PART 2}

1. CONDITION DESCRIPTION

2. ACTION DESCRIPTION

3. CAMERA AND ANGLE

4. AUDIO

5. ALL CONNECTIVITIES

PART 1 - A CLOSING

\section{Length: 00:20}

Lorem ipsum dolor sit amet, consectetuer adipiscing elit, sed diam nonummy nibh euismod tincidunt ut laoreet dolore magna alliquam erat volutpat. Ut wisi enim ad minim veniam, quis nostrud exerci tation ullamcorper suscipit lobortis nisl ut aliquip ex ea commodo consequat. Duis autem vel eum iriure dolor in hendrerit in vulputate velit esse molestie consequat, vel illum dolore eu frengiat nulla facilisis at vero eros et accumsan et iusto odio dignissim qui blandit praesent luptatum zzril delenit augue duis dolore te feugait nulla facilisi. 

and Convergent Interfaces to T-Commerce Applications

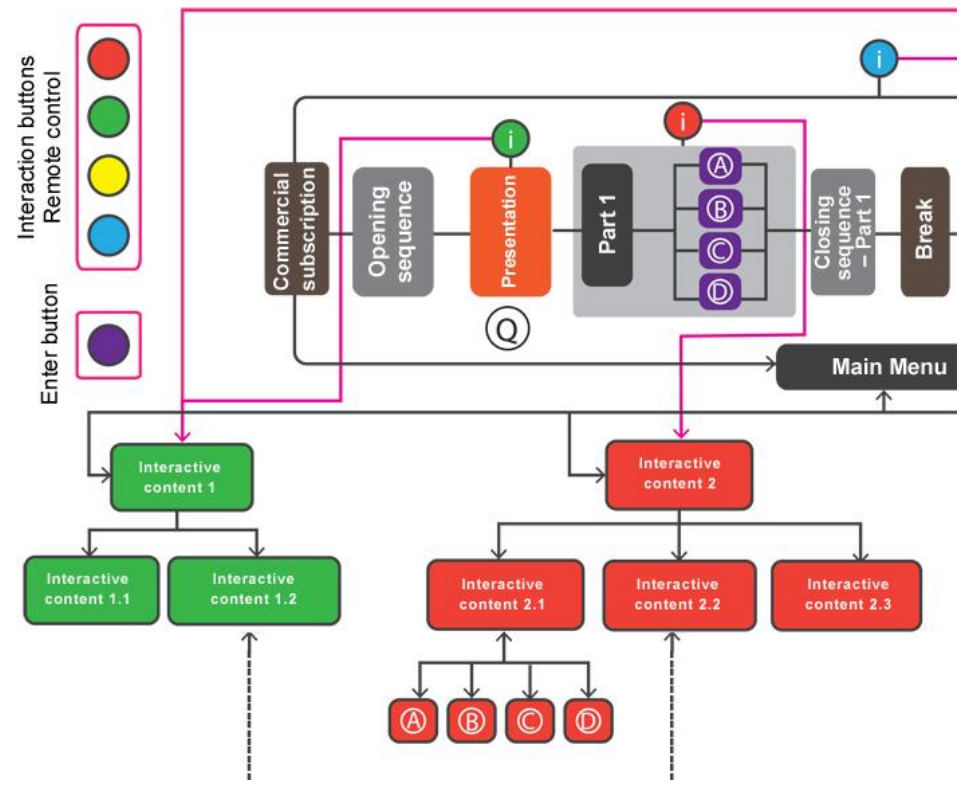

(c)

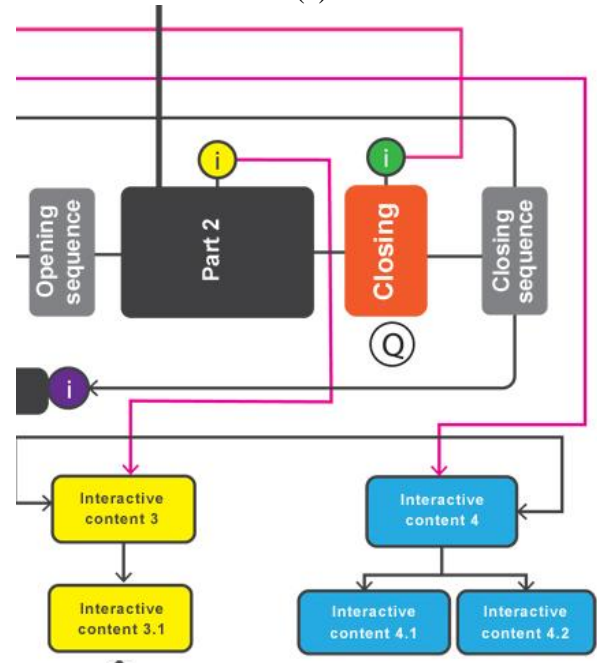

Q) Qcode - download the app for mobile devices

(d)

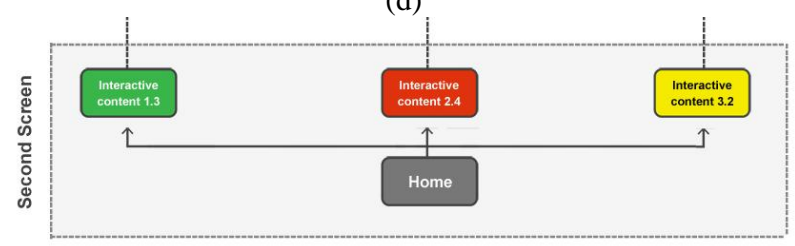

(e)

Fig. 6 TV hybrid script and streaming of a T-commerce application.

Intrinsically, each part has a script aiming to describe and detail-in addition to the scene environment, characters actions, plans and camera movements and audio-the relationship and connection between audiovisual content and application interfaces, flow and interactions available to teleinteractor, as well as connectivity and convergence with other screens. This proposal 
enhances the television streaming, by combining linear and nonlinear instances during show, as well as provides the construction of dialogical relations between content parts and contents connected and distributed on mobile devices.

\section{Conclusions}

This article aims to discuss design perspectives to the design of interfaces connected and converged for t-commerce applications. The study identified the main problems of the development in the linearity of the narrative and temporal flows originated from the television analog condition; and in the absence of dialogical relationships between audiovisual content and interactivity layer, both in scope of the current applications for iDTV, and also in those that employ the use of the second screen. In this context, there is the hypothesis of a hybrid narrative script and flow as design path able to associate the contributions from the linear and nonlinear models, focusing on semantic connectivity and not only technological, between audiovisual narratives and interactive content.

Future developments of this research still consider the extension of the hybridization concept between linear and nonlinear processes to production and post-production stages. It is expected, therefore, the drafting of a method for the development of interactive audiovisual content in the iDTV that would encourage the alignment between the productive processes carried out within the TV stations, audiovisual content producers and interactive content designers. Consequently, it is expected to motivate the development of t-commerce applications capable to transform the relationship between television and its audience, putting the viewer definitely in the active position of teleinteractor, but without mischaracterizing the language of the audiovisual media.

\section{References}

[1] Chaudhry, A. A. 2009. "Publicidade em Novos Meios e as Perspectivas para TV Digital no Brasil." In
TVDigital.br-Conceitos e estudos sobre o ISDB-TB, edited by Squirra, S., and Becker, V. São Paulo: Ateliê Editorial.

[2] Cannito, N. 2010. A televisão na era digital: interatividade, convergência e novos modelos de negócio. São Paulo: Summus.

[3] Murray, J. 2003. Hamlet no Holodeck: o futuro da narrativa no ciberespaço. São Paulo: Itau Cultural: Unesp.

[4] Marcondes Filho, C. 1988. Televisão: a vida pelo vídeo. São Paulo: Moderna.

[5] Moran, T. 1981. "The Command Language Grammars: A Representation for the User Interface of Interactive Computer Systems." International Journal of Man-Machine Studies 15: 3-50.

[6] Leão, L. 1999. O Labirinto da Hipermídia: Arquitetura e navegação no ciberespaço. São Paulo: Iluminuras.

[7] Mcluhan, M. 2002. Os meios de comunicação como extensões do homem. São Paulo: Cultrix.

[8] Munari, B. 2001. Design e comunicação visual. São Paulo: Martins Fontes.

[9] Jenkins, H. 2009. Cultura da Convergência. São Paulo: Editora Aleph.

[10] Schlittler, J. P. 2011. TV digital Interativa: Convergência das mídias e interfaces do usuário. São Paulo: Blucher.

[11] Heineken Legendary Football. https://www.youtube.com/watch?v=dRLZhxMZcbk.

[12] Ad http://www.youtube.com/watch?v=o4hpXgfdoEM.

[13] Kotler, P., and Keller, K. L. 2006. Administração $e$ marketing. São Paulo: Pearson Prentice Hall.

[14] Gawlinski, M. 2003. Interactive television production. Oxford: Focal Press.

[15] Idtv. http://idtv.me/img/shop.jpg.

[16] Klugtv. https://www.youtube.com/watch?v=GBdkrsm4-a4\#t=58.

[17] Klugtv traz o conceito de second screen para a programação de TV. http://www.telaviva.com.br/26/06/2012/klugtv-traz-o-con ceito-de-second-screen-para-a-programacao-de-tv/tl/2855 37/news.aspx.

[18] Carneiro, R. G. 2012. Publicidade na TV Digital: Um mercado em transformação. São Paulo: Aleph.

[19] Johnson, S. 2001. Cultura da Interface: Como o computador transforma nossa maneira de cri-ar $e$ comunicar. Rio de Janeiro: Jorge Zahar Editor.

[20] Cooper, A., Reimann, R., and Cronin, D. 2007. About Face 3: The Essentials of Interaction Design. Indianapolis: Wiley Publishing Inc.

[21] Ramos, J. 1995. Televisão, publicidade e cultura de massa. Petrópolis, RJ: Vozes.

[22] Ministério das comunicações. 


\section{and Convergent Interfaces to T-Commerce Applications}

http://www.mc.gov.br/o-ministerio/273-lex/portarias/253 99-portaria-n-354-de-11-de-julho-de-2012.

[23] Patriota, K. 2009. "Sob demanda, convergente e interativa: a customização da publicidade na televisão digital." In: Televisão Digital: Desafios para comunicação, edited by Squirra, S., and Fechine, Y. Porto Alegre: Editora Sulina.

[24] Pinho, J. B. 2001. Comunicação em Marketing. Campinas, SP: Papirus.

[25] Monteiro, B. 2004. "A Centralidade da peça-piloto no processo de desenvolvimento de roupas de malha: um estudo de caso." Tese de Doutorado em Engenharia de Produção, COPPE/UFRJ.

[26] Blessa, R. 2001. Merchandising no Ponto de venda. São Paulo, Atlas.

[27] Aronchi de Souza, J. 2004. Gêneros e formatos na televisão brasileira. São Paulo: Summus.

[28] Machado, D., Magron, M., and Silva, S. 2002. Mensagem Subliminar: um mergulho no inconsciente humano. Salvador: Intercon.

[29] Garrett, J. J. 2003. The Elements of User Experience. New York, USA: AIGA-American Institute of Graphic
Arts.

[30] Deleuze, G., and Guattari, F. 1995. "Mil platôs - capitalismo e esquizofrenia." (Vol. 1). Tradução de Aurélio Guerra Neto e Célia Pinto Costa, 1st ed. Rio de janeiro: Ed. 34.

[31] Wurman, R. 2005. Ansiedade da Informação 2: Um guia para quem comunica e dá instruções. São Paulo: Editora de Cultura.

[32] Ferrari, P. 2007. Hipertexto, hipermídia: as novas ferramentas da comunicação digital. São Paulo: Contexto.

[33] Vassão, C. A. 2010. Metadesign: ferramentas, estratégias e ética para a complexidade. São Paulo: Blucher.

[34] Chak, A. 2004. Como criar sites persuasivos. São Paulo: Pearson Education do Brasil.

[35] Santaella, L. 2007. Linguagem líquidas na era da mobilidade. São Paulo: Paulus.

[36] Lamardo, R., and Santos Silva, C. E. 2005. "A publicidade e os desafios da convergência." In Encontro ESPM de comunicação e marketing.

[37] Mcluhan, M. 1979. Os meios de comunicação como extensões dos homens. São Paulo: Cultrix. 